\title{
A função da análise na Musica Poetica de J. Burmeister
}

\section{The function of analysis in J. Burmeister's Musica Poetica}

\author{
iD Cassiano de Almeida Barros \\ Universidade do Estado de Santa Catarina, Florianópolis, Santa Catarina, Brasil \\ cassianobarros@hotmail.com
}

\begin{abstract}
Resumo: No último capítulo do tratado intitulado Musica Poetica (1606), Joachim Burmeister formula uma análise musical de um moteto de Orlando di Lasso com o objetivo de ensinar a compositores iniciantes as possibilidades de estudo do repertório vigente, que colocasse em evidência os artifícios e técnicas do processo criativo musical e os disponibilizasse para imitação. Considerando as controvérsias que permeiam a compreensão dessa análise na literatura atual, a pouca atenção dedicada a ela e seu valor histórico como forma de acesso ao repertório seiscentista, desde uma perspectiva hermenêutica, este artigo propõe a releitura dessa análise, recupera e relaciona referências de seu contexto de origem e atualiza sua compreensão em nosso tempo presente, ampliando as possibilidades de percepção e compreensão desse repertório e das técnicas empregadas em sua criação.
\end{abstract}

Palavras-chave: Análise Musical. Poética Musical. Joachim Burmeister. Orlando di Lasso.

\begin{abstract}
In the last chapter of the treatise entitled Musica Poetica (1606), Joachim Burmeister formulates a musical analysis of a motet by Orlando di Lasso, with the aim of teaching beginning composers the possibilities of studying the current repertoire, which would highlight the artifices and techniques of the musical creative process and make them available for imitation. Considering the controversies that permeate the understanding of this analysis in the current literature, the little attention devoted to it and its historical value as a way of accessing the 17th century
\end{abstract}


repertoire, from a hermeneutic perspective, this article proposes the rereading of this analysis, retrieves and relates references from its context of origin and updates its understanding in our present time, expanding the possibilities of perception and understanding of this repertoire and the techniques used in its creation.

Keywords: Musical Analysis. Musical Poetics. Joachim Burmeister. Orlando di Lasso.

Submetido em: 2 de maio de 2020

Aceito em: 20 de novembro de 2020 


\section{Introdução}

Atualmente, a análise musical é reconhecida como uma disciplina constituinte da musicologia (DUNSBY; WHITTALL, 2011). Ainda que, historicamente, sua concepção, função e prática tenham se modificado consideravelmente, hoje, em linhas gerais, Dunsby e Whittall (2011, p. 19), assim como outras referências, relacionam a análise "com a exploração técnica de técnicas composicionais e de estruturas de composições acabadas". Partindo daí, poderíamos compreender a análise como uma atividade cujo foco concentra-se nos processos criativos e nos produtos resultantes do exercício desses processos, na perspectiva de explicá-los e compreendê-los com os mais diversos fins, como a compreensão do repertório e de sua criação por si, o fomento da performance ou o do próprio ato criativo, por exemplo. ${ }^{1}$ Por sua amplitude e relevância, o exercício da análise acompanha a história da poética musical há muito tempo, e se relaciona com ela desde suas primeiras formulações, tais como as de Aristóxeno de Tarento (360 a.C. - 300 a.C.). Sobre isso, Dunsby e Whittall (2011) comentam que:

\footnotetext{
O surgimento da análise, como várias outras disciplinas da musicologia, está fortemente associado ao desenvolvimento gradual da 'composição', não somente como algo grafado no papel, mas como algo criado por um indivíduo e em alguns aspectos expressando a personalidade daquele indivíduo. (DUNSBY; WHITTALL, 2011, p. 21).
}

A ênfase que Dunsby e Whittall (2011) empregam na qualificação do processo criativo pela ação humana nos lembra que todo ato criativo e obra musical situam-se num determinado tempo histórico e contexto cultural, que os condicionam pelas possibilidades que Ihes apresentam e pelos limites que Ihes impõem no

\footnotetext{
1 Para uma definição e descrição mais detalhadas sobre a análise musical, ver: BENT, Ian; POPLE, Anthony. Analysis. In: Grove Music Online. Oxford: Oxford University Press, 2001. Disponível em: https://doi.org/10.1093/gmo/9781561592630.article.41862. Acesso em: 28 abr. 2020.
} 
A função da análise na Musica Poetica de J. Burmeister Cassiano de Almeida Barros

momento de sua realização e conclusão. No entanto, a ideia da expressão da personalidade individual do artista mostra-se como categoria transistórica, por isso, questionável. Já o trabalho de análise operado a partir da perspectiva sócio-histórica que aqui se propõe, pode nos ajudar a observar os diferenciais históricos de cada obra e a especificar lógicas discursivas e condicionamentos materiais e institucionais que possibilitam relativizar e criticar eventuais apropriações anacrônicas.

Para isso, faz-se necessário reconhecer, dentre outros fatores, que os processos analíticos são também marcados por fatores históricos diversos. Bent e Pople (2001, s. p.) nos alertam para o fato de que "subjacente a todos os aspectos da análise como uma atividade está o ponto fundamental de contato entre a mente humana e o som musical, ou seja, a percepção musical". Sabemos, por estudos relacionados à percepção musical, que ela se configura como um processo complexo de mediação entre o ser humano e as coisas do mundo, do qual participam a história individual e a história social, articuladas pela linguagem. Nesse sentido, podemos considerar que todo processo analítico se realiza na contingência do processo perceptivo que o integra e coloca em evidência a historicidade do sujeito que o realiza, do contexto do qual participa e dos processos e fatores que o condiciona. Nessa mesma linha, Bourdieu (1996, p. 331-332) acrescenta que "as categorias empregadas na percepção e na apreciação da obra de arte estão duplamente ligadas ao contexto histórico: associadas a um universo social situado e datado, constituem o objeto de usos eles próprios socialmente marcados pela posição social dos usuários". Assim, podemos considerar que a historicidade de ambos os processos, o criativo de um lado e o analítico do outro, condiciona a compreensão que construímos do repertório que analisamos e nos chama a atenção para a relativização do ponto de vista a partir

\footnotetext{
2 Underlying all aspects of analysis as an activity is the fundamental point of contact between mind and musical sound, namely musical perception.

3 Sobre esses estudos, ver: SANTOS, Cristiele; BARROS, Cassiano. A percepção musical e a apreciação musical: uma revisão de conceitos. In: JORNADA DE ESTUDOS EM EDUCAÇÃO MUSICAL, 6., 2016, São Carlos. Anais [....]. São Carlos: UFSCar, 2016. p. 305-
} 313. 
A função da análise na Musica Poetica de J. Burmeister

Cassiano de Almeida Barros

do qual formulamos nosso juízo e o valor desse mesmo juízo como algo contingente, imperfeito, sempre inacabado e mutável.

Sobre as relações entre a análise musical e a história, Bent e Pople (2001) complementam:

\begin{abstract}
Existe uma relação diferente entre a análise musical e a história da música. Para o historiador, a análise pode configurar-se como uma ferramenta para a investigação histórica. Ele a usa para detectar relações entre estilos, e assim estabelecer cadeias de causalidade que operam ao longo da dimensão do tempo e são ancoradas no tempo por informações factuais verificáveis. [...] Por sua vez, o analista pode ver o método histórico como uma ferramenta para investigação analítica. Seu objeto de estudo configura-se como seções cortadas na história. Quando em análise, elas são atemporais ou "sincrônicas"; elas incorporam relacionamentos internos que o analista procura desvelar. ${ }^{4}$ (BENT; POPLE, 2001, s. p.).
\end{abstract}

Essas ideias sobre a análise musical assumem valor especial quando nos confrontamos com iniciativas antigas de elaboração analítica, tal como a de Joachim Burmeister (1564-1629). Esse músico alemão é reconhecido, hoje, como o autor da primeira análise musical de uma obra completa (DUNSBY; WHITTALL, 2011, p. 2122). Essa análise foi publicada em 1606, no tratado intitulado Musica Poetica e tem como objeto o moteto In me transierunt, de Orlando di Lasso (1532-1594), originalmente publicado em Nuremberg em 1562, por Johann Berg e Ulrich Neuber, na coletânea intitulada Canções sacras a cinco vozes [Sacrae cantiones quinque vocum]. Nessa publicação, a obra não é impressa junto com o escrito da análise e, por essa razão, acredita-se que ela fosse, à época, de amplo conhecimento e de fácil acesso aos leitores do tratado de

\footnotetext{
4 A rather different relationship exists between musical analysis and music history. To the historian, analysis may appear as a tool for historical inquiry. He uses it to detect relationships between 'styles', and thus to establish chains of causality that operate along the dimension of time and are anchored in time by verifiable factual information. (...) In turn, the analyst may view historical method as a tool for analytical inquiry. His subject matter is rather like sections cut through history. When under analysis they are timeless, or 'synchronic'; they embody internal relationships that the analyst seeks to uncover.
} 
A função da análise na Musica Poetica de J. Burmeister Cassiano de Almeida Barros

Burmeister, pois, de outra forma, este texto não cumpriria seu fim didático.

Neste artigo, proponho a releitura dessa análise, a fim de construir uma compreensão sobre as categorias utilizadas na sua formulação, sobre o repertório de que ela trata e sobre a relação entre ela e a função para a qual ela foi originalmente planejada. Para isso, além do texto de Burmeister, utilizaremos também estudos atuais relacionados com ele e suas obras, tais como o de Rivera (In: BURMEISTER, 1993), dedicado ao tratado Musica Poetica, e o de Palisca (2001), dedicado especificamente à análise formulada por Burmeister, além das referências nomeadas pelo próprio músico alemão ou subentendidas como parte de seu horizonte de sentido, tais como Aristóteles, Quintiliano, N. Listenius, G. Dressler, G. Zarlino e outros.

\section{A análise musical e as categorias analíticas de Joachim Burmeister}

Burmeister define a análise musical como a investigação de uma poesia cantada [cantilena] modal e polifônica, por meio da divisão de seus afetos ou períodos, de maneira tal que os artifícios com os quais cada um deles foi produzido possam ser estudados e adotados como modelo para imitação (BURMEISTER, 1993, p. 200201). Nessa definição, o autor delimita as qualidades do objeto de investigação, restringindo-o à música vocal, ou, por analogia, àquela instrumental que a imita, que se constitui conforme a um certo modo, a partir das possibilidades disponíveis no sistema modal vigente, e de forma polifônica, ou seja, a mais de uma voz. De forma inicial, podemos considerar que essas qualidades delimitam as

\footnotetext{
5 Em relação a esse moteto, chama a atenção seu reconhecimento e notoriedade, uma vez que, além de servir como objeto da análise formulada por Burmeister, essa obra é referenciada como modelar por Johannes Kepler (1571-1630), que em sua obra intitulada Harmonia do Mundo [Harmonices Mundi], publicada em 1619, faz apontamentos sobre ela. Seguindo a análise de Burmeister, a dissertação de Elias Walther, defendida na Universidade de Tübingen em 1664, igualmente utiliza essa obra como objeto de investigação, conforme relata Bartel (1997, p. 111).
} 
possibilidades elementares de aparência de verdade reconhecidas como válidas no contexto em que o autor opera.

Essa definição avança na enumeração das cinco partes do processo analítico, assim denominadas: "1. Investigação do modo; 2. Investigação do gênero da melodia; 3. Investigação do tipo de polifonia; 4. Consideração da qualidade; 5 . divisão do poema em afetos ou períodos." (BURMEISTER, 1993, p. 200-201). Essas partes se definem a partir das próprias qualidades já destacadas inicialmente, enquanto abstrações generalizantes que emergem do repertório referenciado como categorias que permitem reconhecer, em cada caso, a forma particular de ocorrência dos materiais e técnicas postos em evidência para imitação.

Na medida em que essas categorias analíticas emergem do repertório, da forma como ele é percebido e compreendido em seu próprio tempo, e são constituídas com o fim específico de evidenciar as formas de uso dos artifícios que lhes são comuns, para a formação de músicos e não-músicos, podemos considerar o valor dessas categorias como ferramentas de acesso a ele hoje, apesar da distância histórica e cultural, desde que esse distanciamento seja considerado no nosso processo de aproximação e suas referências sejam recuperadas, relativizando e ampliando as possibilidades de percepção e compreensão desse repertório atualmente.

No contexto da produção musical seiscentista, que propõe a alteração da materialização sonora mais simples e direta do discurso, aquela produzida pelo orador, para torná-la mais persuasiva, por meio da ação do músico-orador, o compositor, aquele que opera a compositio, se situa como causa eficiente desse processo de adaptação do discurso, de uma forma de expressão para a outra. A ele compete o estudo do texto, a base da operação musical, e sua adaptação sonora, fazendo uso de técnicas de invenção, medidas dispositivas e artifícios elocutivos, preservando o sentido do texto, sua finalidade, qualidade e inteligibilidade, em conformidade aos padrões e formas de expressão consolidados pela tradição então vigente. 
Burmeister finaliza a descrição de suas categorias analíticas justificando a prática da análise como forma de estudo dos artifícios presentes nas obras de música que favoreça o uso deles como modelo para imitação (BURMEISTER, 1993, p. 200-203). Em seu tratado, a imitação é definida como "o estudo e o empenho em conceber e moldar os poemas musicais conforme os exemplos dos mestres compositores, que devem ser habilmente examinadas por meio de análise" (BURMEISTER, 1993, p. 206-207).

Essa ideia da imitação, como princípio poético, consolidou-se historicamente desde Aristóteles, que, em sua Poética, reconhece a imitação como atividade própria da natureza humana, fonte de conhecimento e prazer (ARISTÓTELES, 2017, p. 57) e origem dos processos criativos humanos. A distância temporal entre as formulações de Aristóteles e de Burmeister é longa, mas os elos que as unem são culturalmente fortes e consistentes, forjados sob a influência dos paradigmas racionalistas propostos pelo estagirita e contrafeitos por diversas gerações de músicos, pintores, escultores, escritores, poetas, retores etc. como parte constituinte das práticas artísticas até o século XVIII. Rivera (In: BURMEISTER, 1993, p. XLVII) lembra que "a aquisição da proficiência numa arte por meio da análise e imitação das obras dos mestres é um método que foi ensinado e praticado por séculos". A ideia da imitação é relacional, pois estabelece correspondência entre dois elementos: a coisa imitada e a própria imitação em si. No caso de Burmeister, a ideia da imitação relaciona o trabalho do compositor aprendiz, em formação, ao trabalho dos compositores reconhecidos como mestres, ou seja, aqueles que, devido ao frequente sucesso no cumprimento de determinadas causas, são publicamente reconhecidos como autoridades e, consequentemente, como mestres.

Segundo Burmeister, os verdadeiros e especialmente ilustres mestres, cujas obras qualquer aprendiz poderia imitar, são Clemens non Papa, Orlando di Lasso, Ivo de Vento, Alexander Utendal, Jacobus Regnart, Johannes Knöfel, Jacob Meiland, Antonio Scandello, André Pevernage, Leonhardt Lechner, Luca Marenzio e Gallus Dressler (BURMEISTER, 1993, p. 208-209). Cada um desses 
compositores se destaca pelo exercício de um dos quatro estilos existentes, que são o baixo, o elevado, o médio e o misto. Meiland, Dressler e Scandelo destacam-se pelo exercício do estilo baixo; Clemens non Papa, Ivo de Vento, Regnart, Pevernage e Marenzio, pelo estilo médio; pelo estilo elevado ou sublime, os compositores Utendal, Knöfel e Lechner; pelo estilo misto, Orlando di Lasso.

Para Burmeister, a imitação pode ser feita de duas formas: geral ou específica. É geral quando diversos modelos e compositores são tomados como referência para imitação de invenção, disposição, ornamentação e elaboração contrapontística. É específica quando um único compositor é escolhido como modelo e, nesse caso, diz-se da composição que segue o estilo de Lasso, por exemplo, ou de Marenzio, quando ela imita a maneira particular desse ou daquele compositor de inventar e conectar ideias e períodos (BURMEISTER, 1993, p. 208-209).

Parafraseando Hansen (2019, p. 19), consideramos que, quando o ato da invenção musical fornece ao destinatário, ao ouvinte, os preceitos que evidenciam a construção da obra, ele também Ihes fornece os meios de dissolvê-la, evidenciando o artifício simbólico do ato de fingimento, quero dizer, do ato de produzir algo verossímil. É nesse sentido que a análise opera, como forma de se viabilizar a imitação e a perpetuação dos modelos instituídos pela tradição. E isso não é pouca coisa, especialmente para nós que buscamos realizar esse movimento em direção ao passado para compreendê-lo hoje, em nosso presente. A análise da música antiga, em seus próprios termos, possibilita reconhecer nela qualidades ocultas pelo distanciamento histórico e cultural. Além disso, retomando a paráfrase de Hansen (2019, p. 7), podemos considerar que essa análise nos possibilita reconhecer as diversas possibilidades da escrita numa língua feita de múltiplas línguas e de múltiplos tempos, a música do passado e no passado, libertando as várias línguas que estão aprisionadas numa língua dominante na obra.

O conhecimento dos muitos particulares, da maneira com que cada compositor resolve as dificuldades e problemas que se the 
apresentam na produção de cada obra e de cada gênero discursivo, era construído por meio do exercício analítico, concebido como parte integrante da formação poética, como prescreve Burmeister, por exemplo. A análise musical, no contexto dessa música antiga, atendia à solução de uma única questão, presente em vários tratados dedicados à poética musical, tais como o de C. Bernhard, J. Mattheson e H. C. Koch por exemplo, que seria: como, de que maneira, com que artifícios esta obra analisada cumpre seus objetivos? Nesse contexto quinhentista luterano, do qual participa Burmeister e para o qual ele dirige sua obra, devemos considerar que a produção musical é sempre um produto social datado, que põe em cena representações sonoras das normas sociais em esquemas expressivos que regulam as ações. Essa produção atendia a causas específicas, definidas conforme os espaços de uso público da música - em especial a câmara e a igreja -, o tipo de público ao qual ela era dirigida, as circunstâncias de recepção da obra, sua temática, seu gênero e estilo, e deviam se conformar a elas, a fim de obter a adesão do público para o fim último da representação musical, definido como a promoção do movimento das almas, o deleite e a edificação moral (BURMEISTER, 1993, p. 16-17).

Numa perspectiva pedagógica, Burmeister recomenda ao compositor iniciante que principie sua formação pela imitação de obras pertencentes ao estilo baixo, siga pelo estilo médio, avance pelo elevado e finalize pelo misto (BURMEISTER, 1993, p. 210211). Este último é deixado para o final do processo de formação do compositor provavelmente devido à própria dificuldade de se operar a mistura dos estilos e pela necessidade de conhecê-los em separado antes de juntá-los e misturá-los. Recomenda ainda, numa linda metáfora, que o iniciante preserve essas categorias em mente, de maneira que, "ao começar a imitar, ele não se perca em confusão e puxe a âncora em face de um falso sinal, começando a velejar sem ter selecionado um bom timoneiro para o navio " (BURMEISTER, 1993, p. 210-211).

Considerando o espaço que lhe é dedicado no tratado, Orlando di Lasso certamente foi reconhecido como esse bom timoneiro 
A função da análise na Musica Poetica de J. Burmeister Cassiano de Almeida Barros

que, pelo exemplo de suas obras, deve ter guiado as penas de muitos compositores. Mas, retomando Burmeister, como a natureza e o exemplo não bastariam para a boa formação na arte da música, os preceitos que o músico alemão formulou guiariam, em terra firme, como um farol, as ideias que definiriam o caminho que o barco iria tomar.

O moteto In me transierunt, de Orlando di Lasso, está composto sobre versos dos salmos 88 e 38, dispostos na seguinte sequência:

\section{Quadro 1 - Disposição, referência, e tradução do texto do moteto In me transierunt}

\begin{tabular}{|l|l|l|}
\hline Referência & Texto latino & Tradução para o português $^{6}$ \\
\hline Salmo 88:17 & $\begin{array}{l}\text { In me transierunt irae tuae, et terro- } \\
\text { res tui conturbaverunt me }\end{array}$ & $\begin{array}{l}\text { Passa sobre mim a tua ira, teus terrores } \\
\text { me conturbaram. }\end{array}$ \\
\hline Salmo 38:11 & $\begin{array}{l}\text { Cor meum conturbatum est, dereli- } \\
\text { quit me virtus mea, }\end{array}$ & $\begin{array}{l}\text { Meu coração está conturbado, minha } \\
\text { força me abandonou. }\end{array}$ \\
\hline Salmo 38:18 & $\begin{array}{l}\text { dolor meus in conspectu meo sem- } \\
\text { per: }\end{array}$ & E minha dor está sempre diante de mim. \\
\hline Salmo 38:22 & $\begin{array}{l}\text { ne derelinquas me, Domine, Deus } \\
\text { meus, ne discesseris a me. }\end{array}$ & $\begin{array}{l}\text { Não me abandones, Senhor, Meu Deus, } \\
\text { não te afastes de mim. }\end{array}$ \\
\hline
\end{tabular}

Aparentemente, esta composição não é a primeira a ser escrita sobre esse texto. Há pelo menos uma versão anterior, escrita pelo compositor francês Jean Maillard (ca. 1515-1570) e publicada em 1559 na coleção intitulada "Novas e Notáveis Obras Musicais" [Novum et Insigne Opus Musicum], em Nuremberg, três anos antes da publicação da coleção na qual consta o moteto de Lasso. Não é possível afirmar que Lasso tivesse conhecido esta obra, mas é possível deduzir que sim, considerando a mesma matriz textual de ambos os motetos e as semelhanças de elaboração musical identificadas em uma análise comparativa preliminar dessas obras. Fundamenta essa dedução o princípio imitativo que orientava o processo criativo vigente, conforme prescreve Burmeister e outros

6 Tradução livre elaborada pelo autor. 
A função da análise na Musica Poetica de J. Burmeister

Cassiano de Almeida Barros

autores antes dele, que possibilita relacionar essas obras como sendo uma emulação da outra. Mas esta hipótese precisa ser mais bem estudada em trabalho futuro, pois ela escapa ao escopo desta reflexão.

Ao aplicar suas categorias analíticas ao moteto de Lasso, Burmeister identifica nele as seguintes qualidades:

A obra está delimitada pelo modo frígio autêntico, pois o âmbito integrado de todas as vozes participantes ${ }^{7}$ estende-se de $B a e^{8}$. O âmbito individual das vozes é o seguinte: o discantus está limitado de e a ee; o tenor, de $E$ a e; o bassus, de $B a$ b e, o altus, de $b a$ bb. O âmbito do bassus e do altus é plagal, porque o âmbito dessas vozes é mediado de tal forma que o diatessaron (intervalo de quarta justa) é posicionado abaixo do diapente (intervalo de quinta justa) formado a partir da nota final do modo. A base do temperamento é autêntica, pois o diapente (intervalo de quinta justa) E-B está claramente lá. Além disso, a cadência affinal, que está plenamente formada como uma cadência hexaphonal, está localizada onde o diapente é dividido em duas partes iguais. As cadências plenamente constituídas, especialmente as trifônicas, estão constituídas sobre os graus do modo consolidados pela longa tradição e onde espera-se que sejam encontradas. Os dois semitons da escala do modo estão posicionados em seus lugares apropriados, pois a posição do semitom mais grave está situada no primeiro intervalo do âmbito autêntico, ou seja, entre as notas E-F. O lugar do semitom mais agudo está analogamente posicionado entre as notas B-C. A harmonia tem sua conclusão autêntica e principal em E, ou seja, a nota mais grave do âmbito do tenor, como corresponde ao modo. A obra pertence ao gênero diatônico de melodia, porque seus intervalos estão formados, em sua maioria, pela sequência tom, tom, semitom. A obra pertence ao tipo fraturado de polifonia, pois suas notas são combinadas, umas com as outras, em valores desiguais. A qualidade

\footnotetext{
7 O sistema de sons considerado nessa categoria, de origem medieval, é composto pela escala diatônica que se inicia em G2 e se estende até E5, cujos sons são designados pelas letras $\mathrm{D}-\mathrm{A}-\mathrm{B}-\mathrm{C}-\mathrm{D}-\mathrm{E}-\mathrm{F}-\mathrm{G}-\mathrm{a}-\mathrm{b}-\mathrm{c}-\mathrm{d}-\mathrm{e}-\mathrm{f}-\mathrm{g}-\mathrm{a}-\mathrm{a}-\mathrm{bb}-\mathrm{cc}-\mathrm{dd}-\mathrm{ee}$.

8 Conforme observa Rivera (In: BURMEISTER, 1993, p. 205), em seu tratado intitulado Musica autoschediastike, Burmeister identifica corretamente o âmbito geral das vozes presentes nesse moteto de $A$ a ee, ao invés de $B$ a ee. Contudo, no Musica Poetica ele optou por enfatizar o intervalo E-B por sua proeminência na definição do modo no qual essa obra está escrita. Assim, situa o âmbito de B a ee.
} 
A função da análise na Musica Poetica de J. Burmeister Cassiano de Almeida Barros

dos tetracordes é separada [diezeugmenon], pois ao longo de toda a peça a separação dos tetracordes situa-se entre as notas $A$ e $B$. A obra pode ser dividida em nove períodos. O primeiro compreende o exórdio, que é adornado por duas figuras: fuga realis e hypallage. Sete períodos intermediários constituem o corpo da obra, similar à confirmação do discurso (se é que se pode comparar uma arte cognata à outra). O primeiro deles é adornado por hypotyposis, clímax e anadiplosis; o segundo igualmente, e àquelas figuras soma-se a anaphora; o terceiro é adornado por hypotyposis e mimesis; o quarto igualmente, com a adição da pathopoeia; o quinto é adornado por fuga realis; o sexto, por anadiplosis e noëma; o sétimo, por noëma e mimesis. O último, isto é, o nono período, é como o epílogo de um discurso; apresenta a principal conclusão, também chamada de supplementum da cadência final, que frequentemente é ornamentado por auxesis. Aqui, a principal conclusão é prolongada por uma série de consonâncias produzidas sobre os principais graus do modo que, numa obra polifônica, são articulados com mais frequência que os demais graus. ${ }^{9}$ (BURMEISTER, 1993, p. 204-207, grifos do autor).

Em relação à primeira categoria analítica, que trata da investigação do modo, Burmeister considera uma série de aspectos, tais como o âmbito individual de cada voz e o coletivo do conjunto, a identificação da nota final do modo, a posição do diapente (intervalo

\footnotetext{
9 Tradução livre de parte do capítulo 15 do tratado Musica Poetica, intitulada “Exemplo de uma análise da composição a cinco vozes In me transierunt de Orlando (di Lasso)" [Exemplum Analyseos Cantilenae In me transierunt Orlandi Quinque Vocum]. Segue o texto latino original: Haec Harmonia In me transierunt Orlandi Dilassi elegans et aurea, determinatur Modo Authentâ Phrygiô. Ambitus namque integri omnium Vocum Systematis est, \#B et ee. Singularum verò Vocum Ambitus sic se habent, quod videlicet Disdiscantus inter e et ee; Tenor uterque inter E e; Bassus inter \#B et \#b; Altus inter \#b et \#bb terminetur. Basis etjam Temperamenti est, orthia sive authentica. Intervallum enim Diapente $a b \mathrm{E}$ ad $\mathrm{b}$ vel \#b manifestè datur. Deinde Clausula Affinalis eò loci, ubi haec Diapente in duas partes aequales diffinditur, plenâ, ut [hexaphonos]: Clausula formari solet formatione introducitur. Vocum Alti et Bassi plagalis est Ambitus. Mediatur enim Ambitus earum eò loci, ubi inferiori parti Diatessaron, superiori Diapente attribuitur, Clausulae ijs etjam in locis, quae in hôc Modô ad plenam, praesertim [trephonon], formationem sunt jam longô usu inventa et recepta, formatae ostenduntur. Semitonia etjam compârent utraque in suis quaeque locis. Inferioris enim Semitonij locus est ab imô Ambitus authentici primum intervallum. Superioris est planè idem cum inferioris locô et cetera. Finem Harmonia obtingit in E authenticum et Principalem, qui est, et esse solet Tenoris Ambitus infimus sonus. Secundo pertinet ad Genus Modulationum Diatonicum: quia ejus intervalla ut plurimum formantur per Tonum, Tonum, et Semitonium. Tertiò pertinet ad Genus Antiphonorum Fractum. Sunt enim Soni alteri cùm alteris in non aequali valore connexi. Quartò est Qualitatis Diezeugmenorum. Nam in à et b per totum cantum fit Tetrachordorum disjunctio. Porro haec Harmonia in novem periodos commodissimè distribui potest, quarum prima, continet Exordium, quod est exornatum duplici Ornamento, alterô Fuga Reali; alterô Hypallage. Septem intermediae sunt ipsum Harmoniae Corpus, velut (si ita cum altera aliquâ cognatâ arte comparare liceat) Confirmatio in Oratione. Ex quibus prima Hypotyposi, Climace, et Anadiplosi est exornata; Secunda similiter, cui superaddi potest Anaphora; Tertia Hypotyposi et Mimesi; Quarta modô pari, et insuper Pathopoëiâ; Quinta Fugâ reali; Sexta Anadyplosi et Noëmate; Septima Noëmate et Mimesi; Vltima, scilicet nona periodus, est velut Epilogus in Oratione. Finem haec Harmonia Principalem exhibet, ductum per illa concentuum loca, in quibus Modi, ad quem Harmonia refertur, natura consistit, et quae tota Harmonia solet saepius reliquis sonorum locis attingere, alias vocatum Finalis Clausulae Supplementum, quod usitatissimè ornamenti Auxeseos cultum secum ferre solet.
} 
de quinta justa) e do diatessaron (intervalo de quarta justa) e a posição relativa de ambos, os tipos de cadência e os graus do modo sobre os quais elas estão construídas e o lugar dos semitons na escala. Todos esses aspectos têm implicações práticas no processo criativo, pois o condicionam na medida em que, combinados com as técnicas de contraponto e de elaboração do texto, definem as possibilidades de composição da obra. Além disso, conforme descreve Burmeister, por sua natureza estrutural e convenções de uso, os modos são portadores de potencial expressivo e sua escolha deve condizer com a natureza do texto que ele acompanha. Neste caso em particular, o modo frígio tem potencial para operar matéria lamentosa e chorosa (BURMEISTER, 1993, p. 134-135), equivalente àquela apresentada pelo texto bíblico selecionado.

Em relação à segunda categoria analítica, que trata da investigação do gênero melódico, Burmeister considera a forma de uso da escala do modo na constituição das melodias. Neste caso, importa observar a ocorrência e recorrência de alterações cromáticas (que definem o gênero cromático de melodia), observando suas possibilidades de uso, ou a manutenção predominante da escala do modo que define o gênero diatônico. $O$ uso do gênero enarmônico, o último dentre as possibilidades consideradas, segundo o próprio Burmeister, não é comum em seu tempo (BURMEISTER, 1993, p. 198-199). Vale enfatizar também que, segundo o músico alemão, em seu tempo, o gênero diatônico "é usado em praticamente todos os motetos" (BURMEISTER, 1993, p. 198-199), a exemplo do que se constata na obra analisada de Lasso.

A terceira categoria analítica está dedicada à racionalização do aspecto rítmico das obras polifônicas, considerado por suas qualidades notacionais, ou seja, pela combinação de figuras de valor igual ou diferente e pelo tipo de figuras combinadas, brancas ou negras, representantes de sons relativamente mais longos ou mais curtos entre si. No caso da obra de Lasso, Burmeister a interpreta como sendo do tipo fraturado, ou seja, esta obra caracteriza-se pela combinação simultânea de figuras de valores distintos, com o predomínio de figuras brancas. Esse aspecto da obra permitiria ao 
estudante de composição atentar-se para a relação de dependência ou independência entre as diferentes vozes, conforme os tipos de movimentos que realizam entre si por seu aspecto rítmico, verificando as possibilidades existentes de elaboração da polifonia.

A quarta categoria analítica trata da forma de uso do modo, se natural ou transposta. Toda a discussão sobre essa categoria analítica é construída sobre a consideração do tipo de tetracorde que qualifica o modo, conforme a perspectiva de Boécio (De institutione musica). Nesse sentido, trata de tetracordes separados [diezeugmenon] e tetracordes juntos [synemmenon], também chamados respectivamente de $B$ duralis e $B$ mollaris, que se caracterizam, 0 primeiro, pelo uso da nota diatônica Si natural e, o segundo, pelo emprego da alteração cromática Si bemol. O primeiro é chamado de tetracorde separado pois, segundo Burmeister (1993, p. 139), os tetracordes $E-F-G-A$ e $B-C-D-E$, ambos constituídos pelas mesmas relações intervalares entre seus graus, guardam a distância de um tom entre si e estão, de fato, separados. A fim de resolver essa separação, os teóricos antigos dividiram esse intervalo de um tom ao meio e, fazendo uso do Si bemol, juntaram outro tetracorde ao primeiro, integrando os dois da seguinte maneira E-F-G-A / $A-B b-C-D$, tomando a nota final de um como a nota inicial do outro, ambos também com as mesmas relações intervalares entre seus graus. Nessa perspectiva, este segundo, que faz uso da alteração cromática, é chamado de tetracorde junto, anexado, integrado [synemmenon]. Esta qualidade do tetracorde, atualizada ao tempo de Burmeister, define a qualidade natural ou transposta do uso do modo.

Burmeister considera válido um número restrito de possibilidades de transposição, a saber, apenas aquelas resultantes da realocação do modo uma quarta justa acima ou uma quinta justa abaixo de sua condição natural. Em qualquer caso, essas transposições resultam sempre no uso sistemático da alteração cromática si bemol como parte da escala do modo. Ainda segundo Burmeister, o uso da transposição em sua época é considerado algo novo e moderno, enquanto o uso dos modos em seu estado 
natural é considerado como antigo e mais tradicional (BURMEISTER 1993, p. 136-137). Para Burmeister (1993, p. 136), "a maior parte das instruções sobre a arte da composição são orientadas pelo uso dos modos conforme sua qualidade primeira e mais antiga", e aqueles que desejam compor fazendo uso da qualidade mais nova e recente devem conhecer as possibilidades de transposição indicadas em seu texto. A justificativa para o uso do modo transposto é elaborada, em termos poéticos, pela necessidade de se fazer uso de um determinado registro mais grave ou mais agudo do que aquele disponível pelo modo em sua condição natural, conservando suas qualidades expressivas intrínsecas, uma vez que, na transposição, as relações intervalares entre os graus do modo seriam preservadas. Neste caso do moteto In me transierunt, trata-se do uso do modo em seu estado natural.

Finalmente, a última categoria analítica proposta por Burmeister é de natureza estrutural e propõe "a divisão de uma peça em afetos", o que "significa sua divisão em períodos" (BURMEISTER, 1993, p. 202). ${ }^{10}$ Para aqueles que se dedicam à análise musical, essa tarefa de fragmentar um todo em partes menores não é arbitrária e tampouco indiscriminada. Depende, principalmente, do reconhecimento dos critérios utilizados pelo compositor para estruturar sua obra e das marcas deixadas por ele nesse processo de estruturação. Em sua poética, Burmeister observa que a conclusão harmônica e melódica dos períodos é feita por meio de cadências [clausulae]. Para ele, "nenhuma peça de música pode ser desprovida de cadências, pois a cadência está para a composição assim como a alma está para o corpo" (BURMEISTER, 1993 , p. 116) ${ }^{11}$ e, por isso, recomenda aos iniciantes que não negligenciem a necessidade de cadências em suas obras se eles não quiserem que elas pareçam inanimadas. O lugar da cadência na música deve coincidir com as articulações no texto, tais como a vírgula, os dois pontos e o ponto final (BURMEISTER, 1993, p. 116117). Em termos dialéticos, Burmeister considera que a cadência tanto finaliza o período precedente [terminus ad quem] quanto

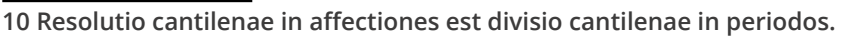

11 Nulla harmonia clausulis carere potest. Est enim clausula in harmonia, velut in corpore animato, anima.
} 
prepara o período subsequente [terminus a quo]. Considerando a correspondência entre as cadências musicais e a pontuação textual e a correspondência entre as unidades textuais e musicais, os períodos, e considerando ainda que, no processo criativo musical, o texto antecede a própria elaboração musical, podemos compreender que a estrutura textual condiciona a estrutura musical, seu todo e suas partes.

Em sua análise, Burmeister divide o moteto de Lasso em nove períodos, indicando em cada um deles a ocorrência de figuras, mas não especifica ou ilustra a maneira como efetua essa divisão. Por essa razão, suas observações foram compreendidas de diferentes maneiras por aqueles que se dedicaram a compreendê-las. Palisca (2001, p. 290), por exemplo, opera sua compreensão do moteto considerando a seguinte divisão dos períodos:

\section{Quadro 2 - Síntese da divisão dos períodos do moteto In me transierunt, de acordo com Palisca (2001)}

\begin{tabular}{|c|c|c|}
\hline Unidade & Função & Poesia \\
\hline 1. Período & Exórdio & In me transierunt irae tuae, \\
\hline $2^{\circ}$. Período & \multirow[t]{7}{*}{ Confirmação } & Et terrores tui \\
\hline $3^{\circ}$. Período & & Conturbaverunt me: \\
\hline $4^{\circ}$. Período & & Cor meum conturbatum est. \\
\hline $5^{\circ}$. Período & & Dereliquit me virtus mea. \\
\hline $6^{\circ}$. Período & & Dolor meus in conspectu meo semper. \\
\hline $7^{\circ}$. Período & & Ne dereliquas me \\
\hline $8^{\circ}$. Período & & Domine Deus meus; \\
\hline $9^{\circ}$. Período & Epílogo & Ne discesseris a me. \\
\hline
\end{tabular}

Fonte: Elaborado pelo autor. Descrição de imagem: quadro informativo.

Porém, Palisca (2001, p. 290) observa que, a partir de uma análise mais atenta à estrutura musical, essa divisão poderia produzir onze períodos, fragmentando o quarto e o sexto períodos acima propostos em duas partes ainda menores. Ruhnke (1955, p. 
A função da análise na Musica Poetica de J. Burmeister

Cassiano de Almeida Barros

164), a partir de uma compreensão distinta da obra e do texto de Burmeister, propôs outra divisão, como segue:

Quadro 3 - Síntese comparativa das propostas de Palisca (2001) e Ruhnke (1955) para a divisão dos períodos do moteto In me transierunt

\begin{tabular}{|c|c|c|c|}
\hline \multirow[t]{2}{*}{ Unidade } & \multirow[t]{2}{*}{ Função } & \multicolumn{2}{|l|}{ Poesia } \\
\hline & & Palisca (2001) & Ruhnke (1955) \\
\hline $1^{\circ}$. Período & Exórdio & In me transierunt irae tuae, & In me transierunt irae tuae, \\
\hline $2^{\circ}$. Período & \multirow[t]{7}{*}{ Confirmação } & Et terrores tui & Et terrores tui \\
\hline $3^{\circ}$. Período & & Conturbaverunt me: & Conturbaverunt me: \\
\hline $4^{\circ}$. Período & & Cor meum conturbatum est. & Cor meum conturbatum est. \\
\hline $5^{\circ}$. Período & & Dereliquit me virtus mea. & Dereliquit me virtus mea. \\
\hline $6^{\circ}$. Período & & $\begin{array}{l}\text { Dolor meus in conspectu meo } \\
\text { semper. }\end{array}$ & $\begin{array}{l}\text { Dolor meus in conspectu meo } \\
\text { semper. }\end{array}$ \\
\hline $7^{\circ}$. Período & & Ne dereliquas me & $\begin{array}{l}\text { Ne dereliquas me Domine } \\
\text { Deus meus; }\end{array}$ \\
\hline $8^{\circ}$. Período & & Domine Deus meus; & Ne discesseris a me. \\
\hline $9^{\circ}$. Período & Epílogo & Ne discesseris a me. & Ne discesseris a me. \\
\hline
\end{tabular}

Fonte: Elaborado pelo autor.

Descrição de imagem: quadro informativo.

A proposta de Ruhnke diverge daquela de Palisca especialmente na compreensão do sétimo e do oitavo períodos. Na compreensão de Palisca, prevalece a estrutura textual sobre a musical e, na compreensão de Ruhnke, os aspectos técnico-musicais assumem maior valor, conforme se verificará adiante na descrição desses períodos.

\section{Interpretação da aplicação da quinta categoria analítica de J. Burmeister}

Retomando a descrição de Burmeister (1993, p. 204-207), assumimos que o primeiro período deste moteto cumpre a função fática do exórdio e está ornamentado pelas figuras fuga realis e hypallage. A primeira é descrita por Burmeister como uma figura de elaboração harmônica e é definida como uma disposição da harmonia na qual todas as vozes imitam um certo afeto [affectio] 
exibido por uma voz da combinação, usando intervalos idênticos ou similares. Pode ser empregada tanto no início das obras quanto em suas partes intermediárias (BURMEISTER, 1993, p. 158-159), conforme se constata neste moteto de Lasso. A hypallage, que também é uma figura de elaboração harmônica, é definida pela inversão do afeto [affectio] de uma fuga, ou seja, configura-se como a inversão dos intervalos que o constituem. Além dessas duas figuras, merecem destaque aqui a ocorrência de outras, não citadas por Burmeister, mas que igualmente chamam nossa atenção, como a hypobole elaborada na parte do discantus no compasso 5 , quando o desenho melódico ultrapassa o âmbito inferior do modo sobre a palavra ira [irae], ilustrando o efeito deste afeto como um descontrole que conduz à superação de limites. As síncopes e dissonâncias entre vozes também são recursos recorrentes neste período, que ajudam a configurar a independência entre elas e a ilustrar a dureza da ira divina.

A constituição do afeto principal também é algo que merece destaque, ainda que nem Burmeister ou outros teóricos depois dele tenham mencionado. $O$ desenho ascendente formado pelo salto inicial de sexta menor e sua condução descendente seguinte por graus conjuntos parecem ilustrar a ação indicada pelo texto de passar sobre [transierunt], especialmente pelo fato do eu lírico do salmo ser representado inicialmente por um som mais grave associado ao texto in me [em mim], a partir do qual se realiza o gesto de elevação [transierunt], seguido de seu decaimento, que encerra o gesto representado. Nos termos de Burmeister, poderíamos identificar aí uma figura chamada de hypotyposis, de elaboração harmônica, que tem por função ilustrar o sentido do texto, dando-Ihe vida e colocando sua ideia diante dos olhos dos ouvintes (BURMEISTER, 1993, p. 174-175), constituindo-se em evidência artificialmente produzida para promover no ouvinte sua persuasão. Samuel Quickelberg (1529-1567), o primeiro biógrafo de Lasso, destacou inclusive a habilidade que esse compositor tinha de "descrever um objeto quase como se ele estivesse diante dos olhos" (QUICKELBERG apud HAAR, 2001, s. p.)..12 Na Figura 1, reproduzida

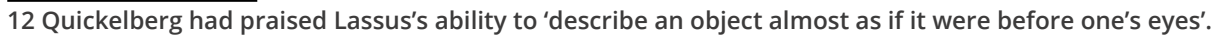


A função da análise na Musica Poetica de J. Burmeister Cassiano de Almeida Barros

a seguir, os destaques em azul representam as entradas do afeto principal da fuga, e os destaques em vermelho, as entradas desse afeto invertido, a hypallage; em amarelo, está destacada a hypobole. Este período se estende do primeiro ao vigésimo compasso e é articulado por uma cadência principal, ou seja, que se encerra numa conjugação de terça e quinta sobre a nota final do modo. Apresenta o argumento principal da obra, a diferença entre o eu lírico, a representação do homem, por sua condição terrena, imperfeita e corrompida, e Deus, salvador e onipotente, que projeta sobre o homem sua ira, como punição por seus atos.

Figura 1 - Fragmento do moteto In me transierunt, de Orlando di Lasso compassos 1-20.

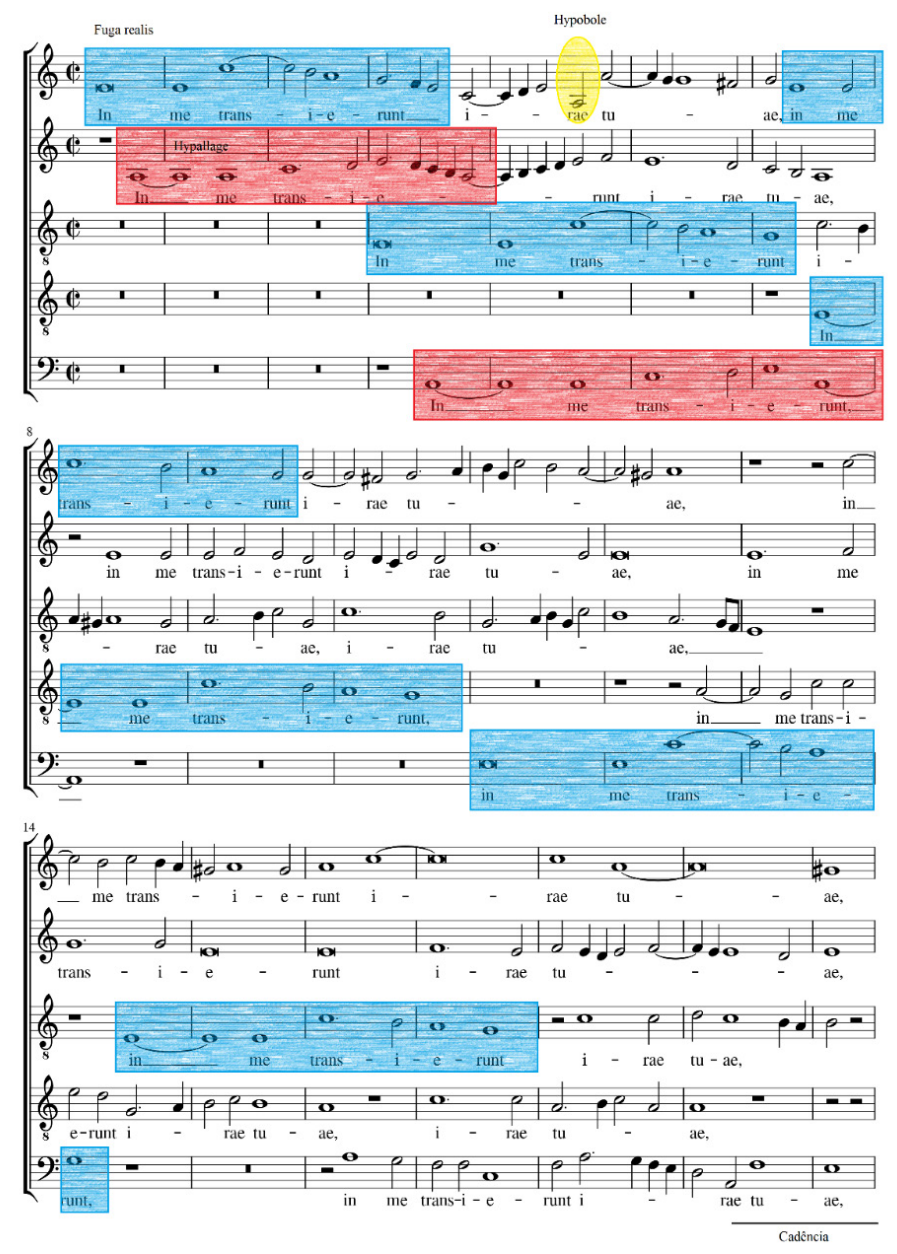

Fonte: LASSO, 1562. Transcrição da primeira edição feita pelo autor.

Descrição da imagem: Figura utilizada como ilustração da ornamentação do primeiro período do moteto In me transierunt, de O. di Lasso. 
A função da análise na Musica Poetica de J. Burmeister Cassiano de Almeida Barros

O segundo período inicia a confirmação do argumento apresentado no exórdio, estende-se do compasso 20 ao compasso 26 e é articulado por uma cadência do tipo peregrina, que se encerra numa conjugação de terça e quinta sobre o segundo grau do modo. ${ }^{13}$ Retomando a descrição de Burmeister (1993, p. 204-207), assumimos que este período está ornamentado pelas figuras hypotyposis, clímax e anadiplosis. A hypotyposis, destacada em azul na Figura 2, parece ser utilizada para representar a estupefação e consequente paralisia ocasionada pelo terror, ao relacionar ao texto uma melodia estática, produzida pela repetição de uma mesma nota. O clímax, uma figura de elaboração melódica, orienta a repetição do texto e da música em gradação de altura (BURMEISTER, 1993, p. 180-181), como se observa na linha do bassus e do discantus, entre os compassos 21 e 26. A anadiplosis, por sua vez, é um ornamento da harmonia que consiste na duplicação da mimesis (BURMEISTER, 1993, p. 166-167). Esta, por sua vez, ocorre quando um grupo de vozes mais próximas realiza um noëma (um trecho elaborado em contraponto simples - nota contra nota) e ele é imitado em seguida por outro grupo de vozes, mais agudo ou mais grave que o primeiro. No moteto de Lasso, essas combinações de vozes são realizadas na seguinte sequência: Tenor1-Tenor2-Alto (afeto) / Discantus-Bassus (imitação do afeto - mimesis) / Tenor2-Alto (segunda imitação do afeto) / Tenor1-Discantus-Bassus (repetição da mimesis - anadiplosis), conforme pode ser verificado na Figura 2 , reproduzida a seguir.

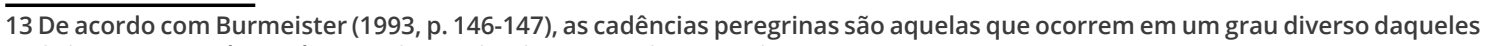
mais importantes do modo, ou seja, o primeiro, o terceiro e o quinto. 
A função da análise na Musica Poetica de J. Burmeister

Cassiano de Almeida Barros

Figura 2 - Fragmento do moteto In me transierunt, de Orlando di Lasso - compassos 20-26.

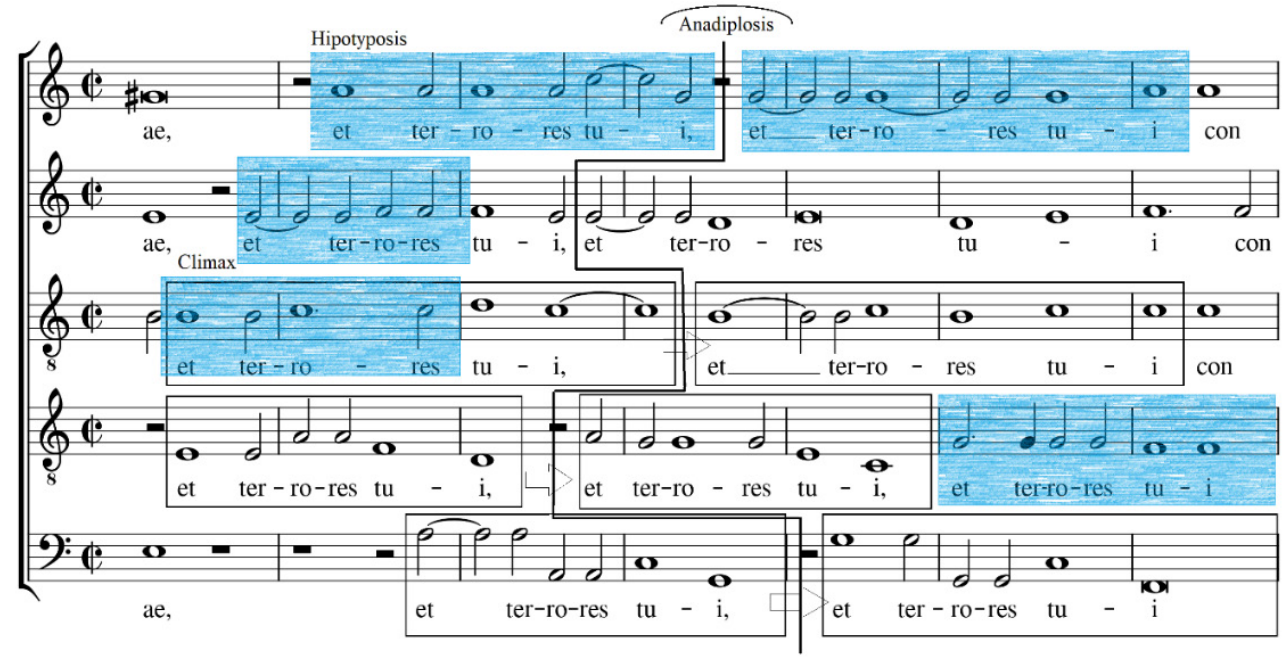

Fonte: LASSO, 1562. Transcrição da primeira edição feita pelo autor.

Descrição da imagem: Figura utilizada como ilustração da ornamentação do segundo período do moteto In me transierunt, de O. di Lasso.

O terceiro período estende-se do compasso 26 ao compasso 32 e é articulado por uma cadência peregrina que se encerra sobre o sétimo grau da escala do modo. Retomando a descrição de Burmeister (1993, p. 204-207), assumimos que este período esteja ornamentado pelas figuras hypotyposis, clímax e anadiplosis, como o período anterior, mais a anaphora. A primeira figura, a hypotyposis, é pensada pela perspectiva de se produzir a representação geral da conturbação decorrente do terror divino e expressa pelas diversas repetições do texto entre grupos de vozes, que colocam diante dos olhos dos ouvintes a ilustração do efeito do terror sobre o eu lírico do salmo. O clímax é utilizado para produzir a gradação melódica na linha do bassus, entre os compassos 28 e 32, destacada em azul na Figura 3. Neste período, a anadiplosis constitui-se a partir da seguinte combinação de vozes: Discantus-AltusTenor1 (afeto) / Tenor1-Tenor2-Bassus (imitação do afeto - mimesis) / Discantus-Altus-Tenor1 (segunda imitação do afeto) / Tenor2-Bassus (repetição da mimesis - anadiplosis), conforme se verifica na Figura 3 a seguir. A anaphora, segundo Burmeister, é um ornamento de elaboração harmônica e melódica que ocorre pela repetição de um 
A função da análise na Musica Poetica de J. Burmeister Cassiano de Almeida Barros

padrão de alturas similar em várias, mas não em todas as vozes da composição. Ocorre à maneira de uma fuga, embora de fato não seja (BURMEISTER, 1993, p. 184-187). Esse ornamento ocorre entre as vozes Tenor1-Bassus-Tenor1, destacado em laranja na Figura 3, Tenor2-Discantus, destacado em amarelo, e entre Discantus-Tenor2, destacado em bege, conforme ilustra a Figura 3.

\section{Figura 3 - Fragmento do moteto In me transierunt, de Orlando di Lasso - compassos 26-32.}

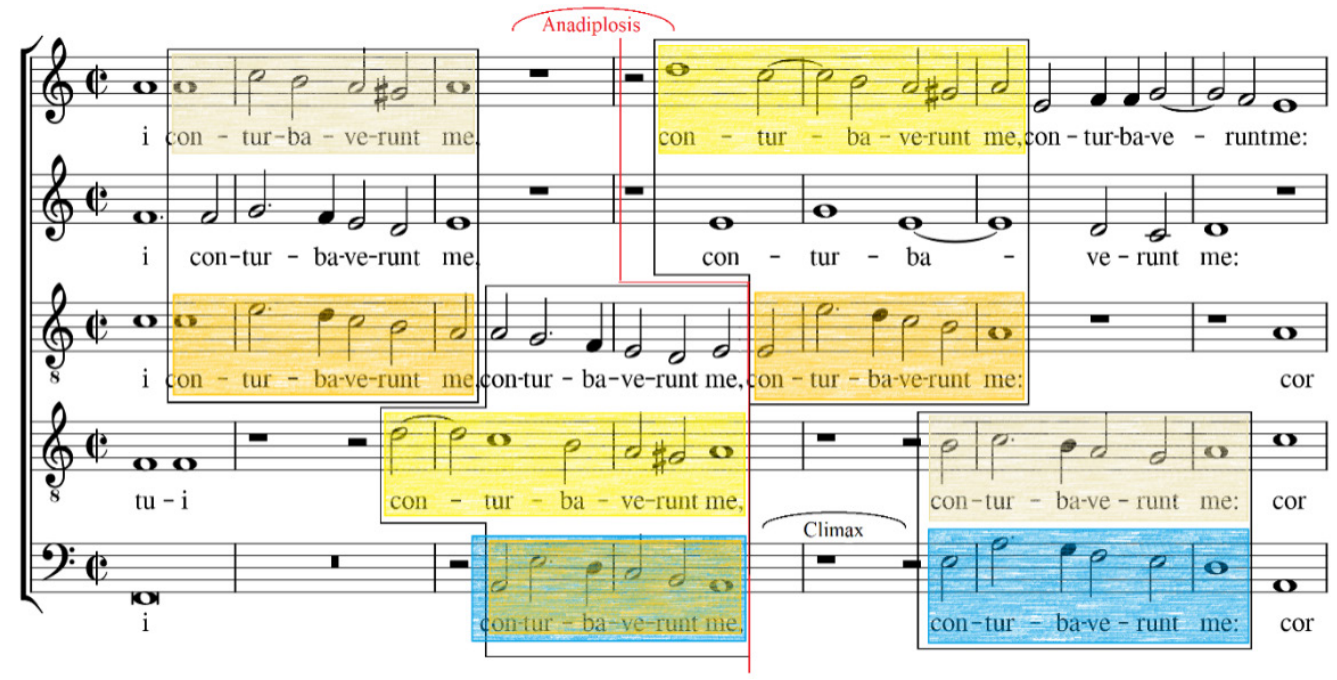

Fonte: LASSO, 1562. Transcrição da primeira edição feita pelo autor.

Descrição da imagem: Figura utilizada como ilustração da ornamentação do terceiro período do moteto In me transierunt, de O. di Lasso.

O quarto período estende-se do compasso 32 ao 41 e é articulado por uma cadência menos principal [minus principalis], que se encerra no quarto grau da escala do modo. ${ }^{14}$ Retomando a descrição de Burmeister (1993, p. 204-207), assumimos que este período esteja ornamentado por hypotyposis e mimesis. Primeiramente, a hypotyposis está elaborada de tal maneira que a alternância entre o grupo de vozes formado pelo Bassus-Tenor2-Tenor1 e o Altus

\footnotetext{
14 Em relação ao modo frígio, segundo Burmeister (1993, p. 146-147), a cadência menos principal, ou secundária, é aquela que se encerra sobre o quarto grau do modo. Sua definição é a seguinte: “Uma cadência menos principal é assim chamada porque sua conclusão ocorre no lugar onde a cadência principal está quando o sistema modal é invertido (do modo autêntico ao plagal). Pois a nota que se constitui como princípio no modo autêntico torna-se mediana no modo plagal, onde ela não é principal e primeira na constituição modal, mas sim secundária e menos principal". [Minus Principalis, sic propterea vocabitur, quod eo quidem loci Finis fit, ubi Principalis, sed inversô Modorum systemate. Nam sonus is, qui Modis Authentis Principium est, in Modis Plagalibus est Emmesepistrophus, qui principalis non est et primus in constitutione Modi, sed secundarius, atque ita minus principalis.] (BURMEISTER, 1993, p. 146-147).
} 
reproduz o tactus característico da batida do coração, conforme citado no texto cor meum [meu coração], presentificando o órgão pela analogia ao som de seu ato de pulsar, conforme se observa na Figura 4, entre os compassos 32 e 35. Em seguida, essa figura é reelaborada, a fim de produzir novamente o efeito da conturbação pela repetição do texto conturbatum est entre grupos de vozes, em valores rítmicos mais curtos que os anteriores, que marcavam o tactus. A mimesis é produzida neste período pela imitação do fragmento conturbatum est entre os seguintes grupos de vozes: Bassus-Tenor2-Tenor1-Altus (afeto) / Tenor2-Tenor1-Altus-Discantus (imitação do afeto - mimesis) / Bassus-Tenor2-Tenor1-Altus (nova imitação do afeto com cadência), destacados em azul na Figura 4. Além dessas figuras indicadas por Burmeister, Palisca identifica ainda o uso do clímax na elaboração da linha do Bassus, entre os compassos 37 e 40, destacado em laranja na Figura 4, e do auxesis - figura de elaboração harmônica definida por Burmeister como o crescimento e elevação de uma harmonia consonante sobre um texto que é repetido uma, duas, três ou mais vezes (BURMEISTER, 1993, p. 172-173) - entre as partes do Tenor1 e Discantus ao longo dos compassos 32 e 35, quando a melodia do tenor se eleva uma oitava, conforme se verifica na Figura 4. 
A função da análise na Musica Poetica de J. Burmeister

Cassiano de Almeida Barros

Figura 4 - Fragmento do moteto In me transierunt, de Orlando di Lasso compassos 32-41.
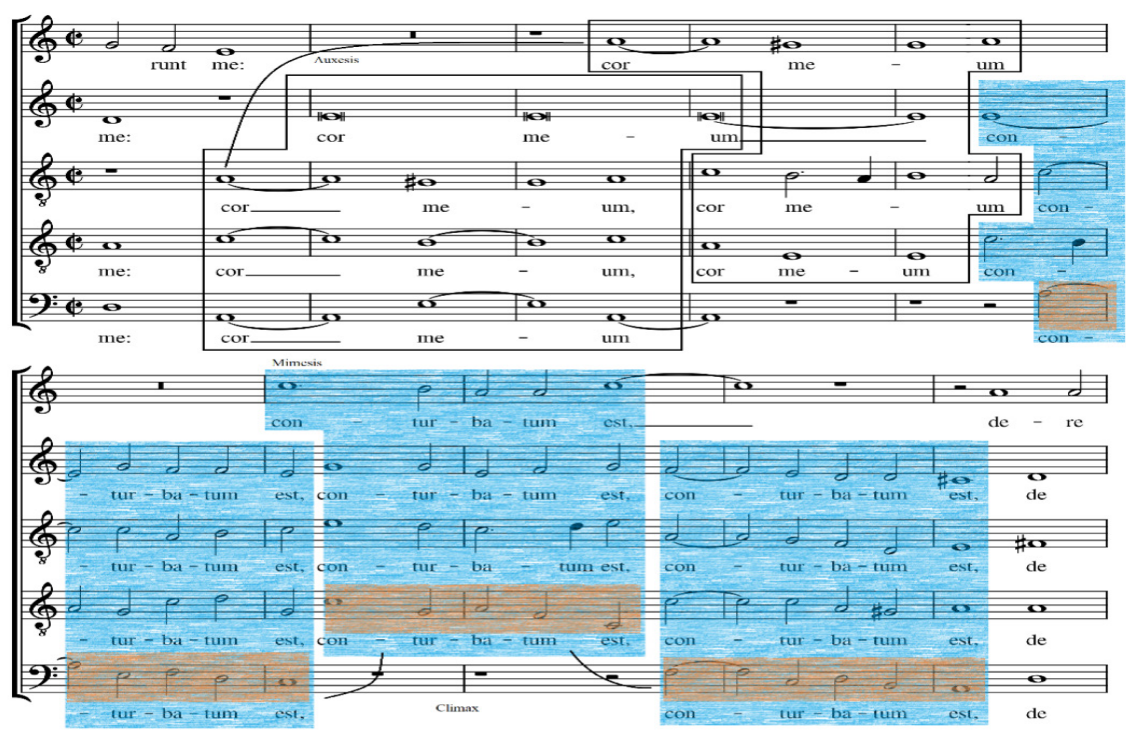

Fonte: LASSO, 1562. Transcrição da primeira edição feita pelo autor.

Descrição da imagem: Figura utilizada como ilustração da ornamentação do quarto período do moteto In me transierunt, de O. di Lasso.

O quinto período estende-se do compasso 41 ao 46 e é articulado por uma cadência principal, que ocorre sobre o primeiro grau do modo. Retomando a descrição de Burmeister (1993, p. 204-207), assumimos que ele esteja ornamentado pelas figuras hypotyposis, mimesis e pathopoeia. Podemos reconhecer a primeira delas como representação do enfraquecimento expresso pelas palavras dereliquit me virtus mea [me abandona minha força], que pode ser associado ao movimento descendente que caracteriza a linha melódica do Discantus. Assim como essa ideia pode ser associada à repetição de notas seguida pelo movimento descendente da linha melódica do Altus, ou a hypobole presente na linha do Bassus, que encerra a linha melódica deste período numa nota grave fora do âmbito do modo, de fato, a nota mais grave utilizada em toda a obra, ilustrando a inanição daquele que não possui mais forças para se mover e se prostra ao chão. A mimesis pode ser compreendida pela imitação do Discantus que as demais vozes do conjunto realizam nos compassos 41 e 42, e a imitação do 
A função da análise na Musica Poetica de J. Burmeister Cassiano de Almeida Barros

Tenor 1 pelas demais vozes nos compassos 44 e 45, destacados em azul na Figura 5. A pathopoeia, segundo Burmeister, é uma figura de elaboração harmônica que consiste no emprego de semitons estranhos ao modo ou ao gênero de melodia, com a finalidade de mover os afetos (BURMEISTER, 1993, p. 174-175). Essa figura pode ser identificada neste período nas partes do Tenor1 e Tenor2, destacados em cinza na Figura 5, constituindo harmonias não ouvidas até então nesta obra, ampliando seu potencial expressivo por meio da exploração desse efeito harmônico e melódico, que parece representar o distanciamento entre o eu lírico e seu Deus por meio do distanciamento sonoro decorrente da alteração cromática. As conjugações $G-B b-D$ (compasso 43) e E-G\#-B (compasso 46) são estranhas entre si, não participam conjuntamente de nenhum modo e não se relacionam sob nenhum aspecto da teoria modal quinhentista conforme proposta por Burmeister. Sua exploração conjunta numa obra justifica-se por seu valor expressivo e seu sentido depende do texto ao qual se vincula. Neste caso, poderia representar a condição terrena do eu lírico, em estado de abatimento e morte, em contraste à posição elevada de seu Deus, em estado de graça e vida eterna, como poderia representar também a mudança de estado, da vida para a morte, reproduzindo a queda adâmica, da qual o fiel, por meio da Graça, busca se libertar. ${ }^{15}$

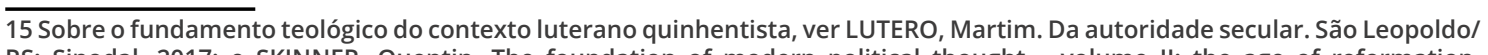
RS: Sinodal, 2017; e SKINNER, Quentin. The foundation of modern political thought - volume II: the age of reformation. Cambridge: Cambridge University Press, 2004. 
A função da análise na Musica Poetica de J. Burmeister

Cassiano de Almeida Barros

Figura 5 - Fragmento do moteto In me transierunt, de Orlando di Lasso compassos 41-46.

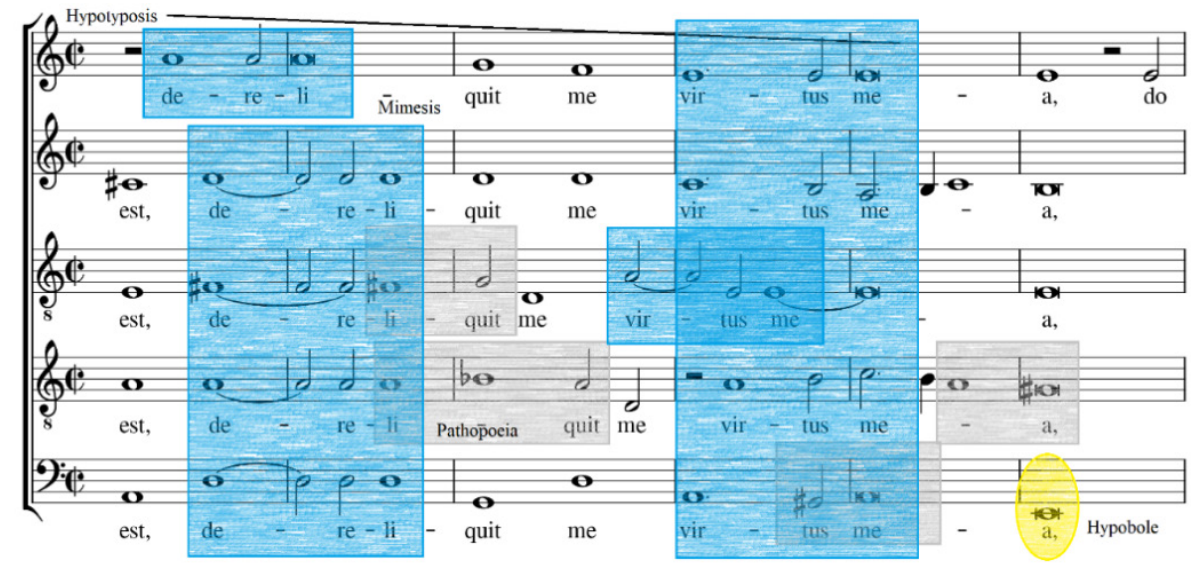

Fonte: LASSO, 1562. Transcrição da primeira edição feita pelo autor.

Descrição da imagem: Figura utilizada como ilustração da ornamentação do quinto período do moteto In me transierunt, de O. di Lasso.

O sexto período estende-se do compasso 47 ao compasso 67 e é articulado por uma cadência menos principal que se encerra sobre o quarto grau da escala do modo. Segundo Burmeister (1993, p. 204-207), este período está ornamentado pela fuga realis. Podemos identificar a ocorrência dessa figura sobre o texto in conspectu meo semper, entre os compassos 52 e 67, cujas entradas do afeto estão destacadas em azul na figura 6. Antes, porém, o texto dolor meus é ornamentado por hypotyposis, pathopoeia e anaphora, conforme observa Palisca (2001, p. 300-303). A hypotyposis consiste na representação sonora da dor expressa pelo eu lírico, realizada pelo uso do semitom diatônico e-f na parte do Discantus ou sua inversão F-E na parte do Tenor2, ou no uso do semitom estranho ao modo, que configura uma pathopoeia, presente nas partes do Tenor1 e Bassus, destacada em amarelo. A anaphora consiste na repetição da parte do Tenor 1 pelo Bassus, ambas as vozes acompanhadas pelo Altus, conforme se observa na Figura 6 reproduzida abaixo. 
A função da análise na Musica Poetica de J. Burmeister

Cassiano de Almeida Barros

Figura 6 - Fragmento do moteto In me transierunt, de Orlando di Lasso - compassos 46-67.
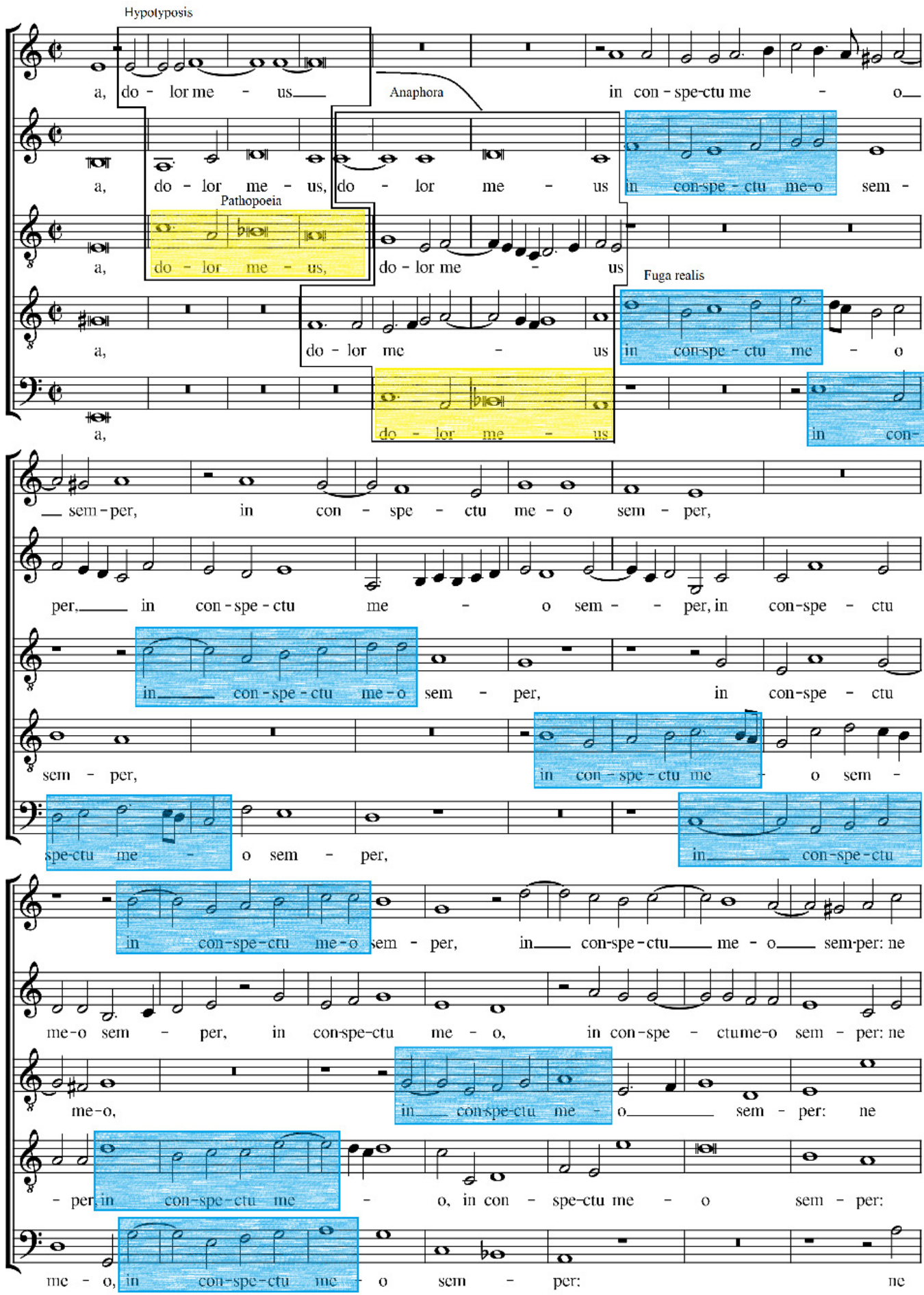

Fonte: LASSO, 1562. Transcrição da primeira edição feita pelo autor.

Descrição da imagem: Figura utilizada como ilustração da ornamentação do sexto período do moteto In me transierunt, de O. di Lasso. 
Retomando a descrição analítica de Burmeister (1993, p. 204207), assumimos que o sétimo período esteja ornamentado por anadiplosis e noëma. Palisca (2001) e Ruhnke (1955) divergem sobre a dimensão deste período, o primeiro por reconhecer uma cadência entre os compassos 72 e 73 e julgá-la como uma articulação entre períodos, e o segundo por não reconhecer a efetividade dessa cadência na articulação das ideias, não encontrar pontuação no texto que a justifique e entender a conclusão do período apenas no compasso 77, onde ocorre uma cadência menos principal sobre o quarto grau da escala do modo. De fato, conforme se observa na Figura 7, a cadência apontada por Palisca parece ter pouca efetividade harmônica e rítmica devido ao fato de sua resolução ser bastante curta e desarticulada ritmicamente entre as vozes, que se sucedem na continuidade da música, o que descaracteriza qualquer ideia de pontuação da música ou do texto ao qual ela está vinculada. Nesse sentido, acompanhamos Ruhnke em sua percepção e conclusão.

Nesse período, podemos reconhecer a anadiplosis como um ornamento que se configura a partir da repetição de uma mimesis conforme a seguinte combinação de vozes: Tenor1 (afeto - destacado em azul escuro na Figura 7) / Bassus-Altus-Discantus (imitação do afeto - mimesis, destacada em azul claro) / Tenor2-Altus (nova imitação do afeto, destacada em verde escuro) / Discantus (repetição da mimesis - anadiplosis, destacada em verde claro) / Bassus (nova imitação do afeto, destacada em amarelo) /Tenor2-Tenor1-Altus (repetição da mimesis - anadiplosis, destacada em bege). Nesta ocorrência da anadiplosis, podemos constatar a alternância entre uma voz individual e um grupo de vozes, primeiro de forma espelhada (solo - grupo / grupo - solo) e depois pela repetição da formação inicial (solo - grupo). Os fragmentos em grupo constituem noëmas, ou seja, trechos de contraponto simples, entre notas de mesmo valor rítmico, à proporção de nota contra nota. Entre a parte do Bassus e a parte do Tenor 2, nos compassos 68-71, encontramos a repetição do mesmo padrão intervalar, mas em altura diferente, configurando o que nos termos de Burmeister podemos entender como uma anaphora. Na parte do Bassus, entre os compassos 68 e 72, encontramos também a repetição da mesma linha melódica com as mesmas notas, o que Burmeister chama de palillogia 
A função da análise na Musica Poetica de J. Burmeister Cassiano de Almeida Barros

(BURMEISTER, 1993, p. 178-179). Finalmente, sobre o texto Domine Deus meus, Lasso elaborou a composição dividindo as vozes em dois grupos (Bassus-Tenor2, destacado em vermelho / Tenor1-AltusDiscantus, destacado em rosa na Figura 7) que se imitam, fazendo uso de contraponto simples entre as vozes de cada grupo. Neste caso, nos termos de Burmeister, podemos identificar a mimesis e o noëma como formas de elaboração que imprimem veemência à realização do vocativo que o texto apresenta. A cadência menos principal que articula este período sobre o quarto grau do modo faz convergir o coletivo de vozes num mesmo ponto, dando força à representação.

Figura 7 - Fragmento do moteto In me transierunt, de Orlando di Lasso compassos 67-77.

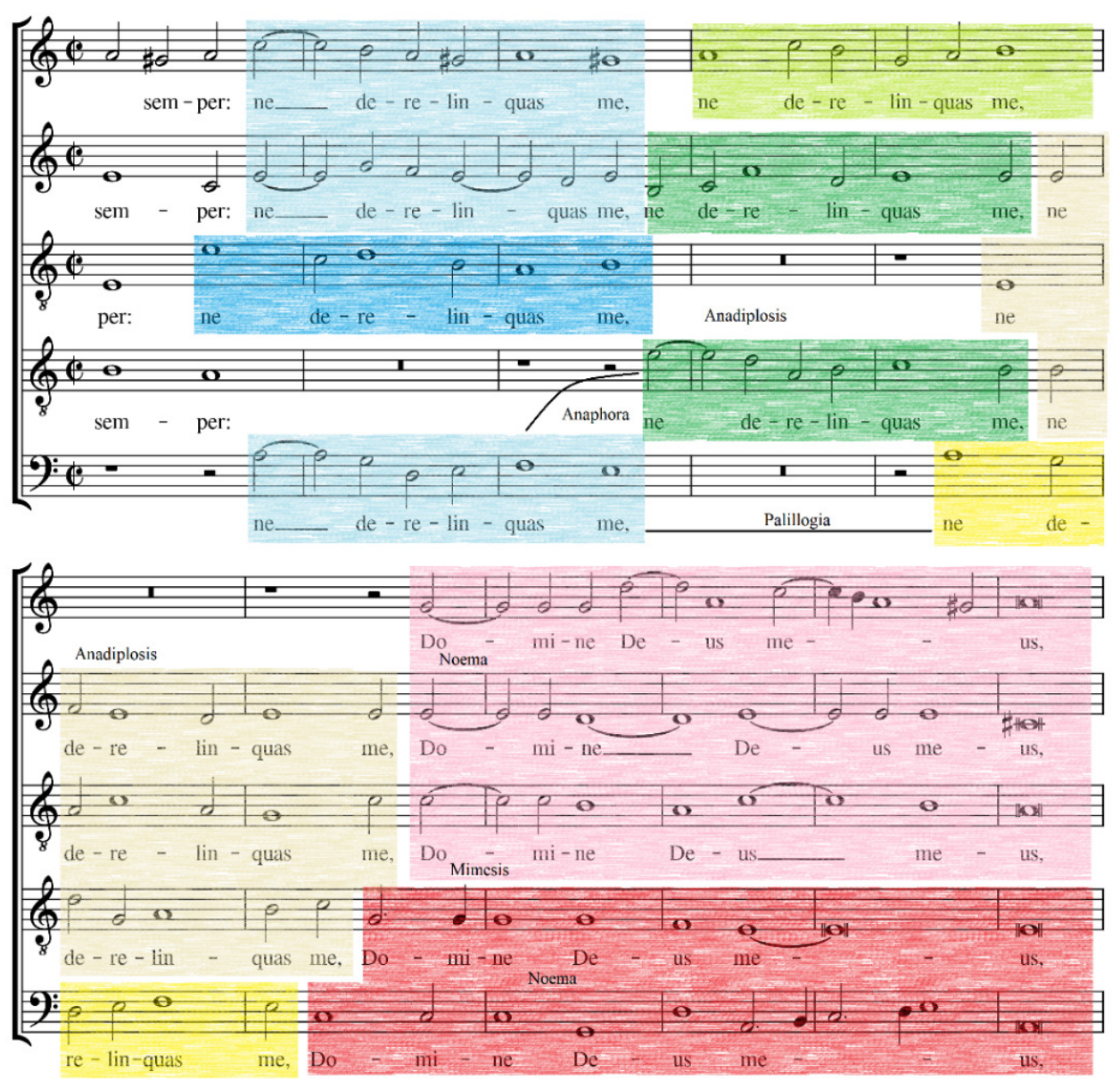

Fonte: LASSO, 1562. Transcrição da primeira edição feita pelo autor.

Descrição da imagem: Figura utilizada como ilustração da ornamentação do sétimo período do moteto In me transierunt, de O. di Lasso. 
O oitavo período estende-se do compasso 78 ao 84 e é igualmente articulado por uma cadência menos principal que se encerra sobre o quarto grau da escala do modo. Retomando a descrição de Burmeister (1993, p. 204-207), assumimos que ele esteja ornamentado pelas figuras noëma e mimesis. Este período está formulado sobre o texto ne discesseris a me, que é repetido. Sua primeira exposição constitui-se à maneira de um noëma no qual todas as cinco vozes participam, dando continuidade ao caráter coletivo constituído pelo final do período anterior, mas elaborado agora sobre o terceiro grau da escala do modo, conforme se observa na Figura 8, reproduzida a seguir. A oscilação entre o quarto grau do modo, que encerra o período anterior, e o terceiro grau, que inicia este período, coloca o Deus evocado e o eu lírico que o evoca em planos distintos, o primeiro mais elevado que o segundo, assim como configura o vocativo como algo naturalmente mais forte e presente, porque mais agudo, e a súplica que o segue como algo mais grave e suave. A repetição do texto está elaborada à maneira de uma mimesis, que opera a imitação do Altus, destacado em azul claro na Figura 8, pelo grupo de vozes formado por Tenor2-Tenor1-Discantus. Além disso, conforme aponta Palisca (2001), a parte do Discantus apresenta nova palillogia, pela repetição literal da mesma melodia.

Figura 8 - Fragmento do moteto In me transierunt, de Orlando di Lasso compassos 78-84.

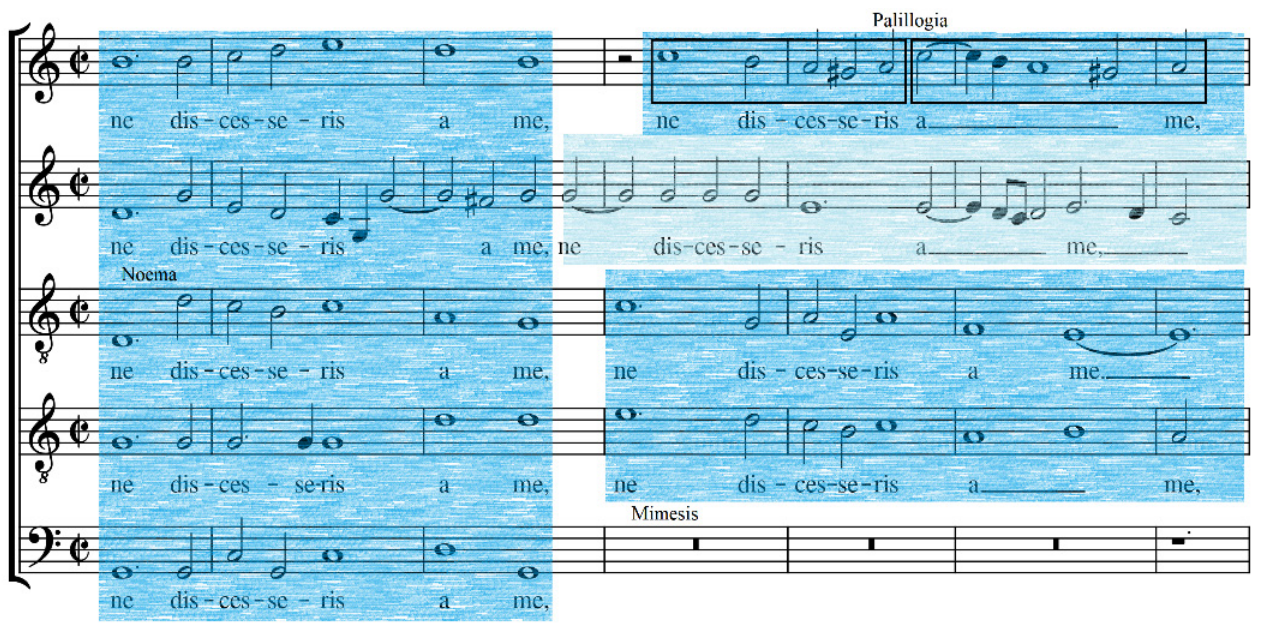

Fonte: LASSO, 1562. Transcrição da primeira edição feita pelo autor.

Descrição da imagem: Figura utilizada como ilustração da ornamentação do oitavo período do moteto In me transierunt, de O. di Lasso. 
A função da análise na Musica Poetica de J. Burmeister Cassiano de Almeida Barros

Por último, o nono período estende-se do compasso 84 ao 87, é concluído pela cadência principal e é chamado de supplementum da cadência final. Recebe este nome de suplemento provavelmente para configurar a ideia de expansão do discurso, por meio de repetição e elaboração, que esclarece e define seu sentido de forma mais precisa. Distingue-se daquilo que possa ser considerado essencial ou necessário para assumir um caráter de complemento, como sugere a última nota da parte do Tenor1, que é sustentada ao longo de todo este período final, como referência sobre a qual todo o trecho é elaborado. Não é por acaso que esta é a nota final do modo, o primeiro grau de sua escala. Nesse caso do moteto de Lasso, esta parte comporta a repetição do último verso da poesia, elaborada pela repetição de cadências que reafirmam o modo em elaborações consonantes, configurando o ornamento que, nos termos de Burmeister, pode ser chamado de auxesis (BURMEISTER, 1993, p. 172-173).

Exemplo 9 - Fragmento do moteto In me transierunt, de Orlando di Lasso compassos 84-87.

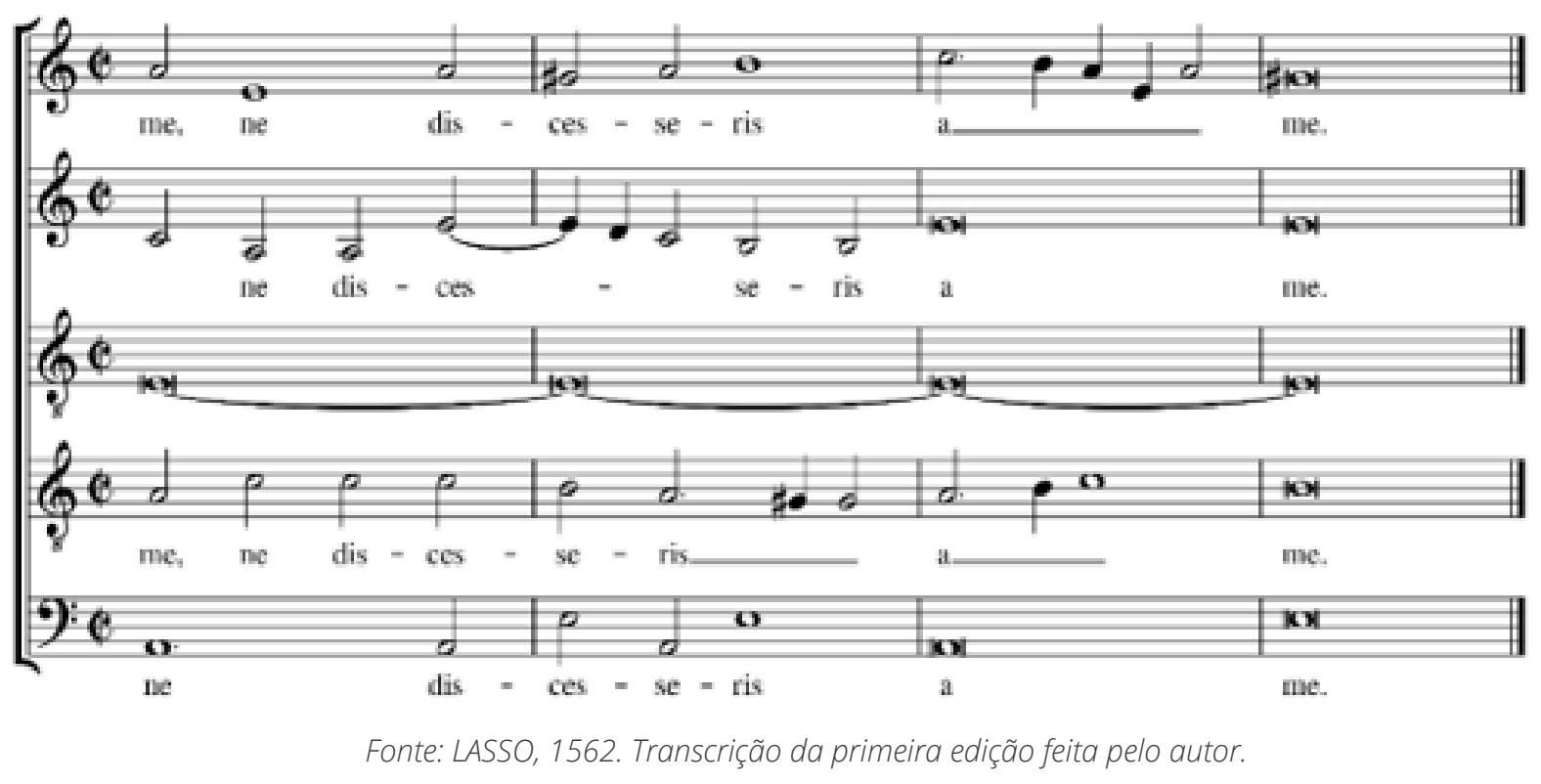

Descrição da imagem: Figura utilizada como ilustração da ornamentação do nono período do moteto In me transierunt, de O. di Lasso. 


\section{Considerações Finais}

A partir dos preceitos formulados por Burmeister, a identificação dos períodos e das figuras no repertório conforme o processo analítico possibilita colocar em evidência o artifício compositivo, tanto pela consideração da técnica quanto de seu efeito no contexto da obra. A operação das técnicas e efeitos, por sua vez, evidencia o caráter teleológico do processo criativo e a relação entre ele e o processo de recepção da obra. Seria possível ainda avançar na reflexão sobre o processo de composição, considerando a extração do artifício para se chegar ao material próprio da invenção. Desse processo, acredito que o que resultaria seria uma linha melódica de cantochão, semelhante às monodias religiosas medievais, que apresentam a elaboração polifônica como potência, assim como essa, em sua forma mais simples, a poucas vozes elaboradas à proporção de nota contra nota, apresentaria em potência as possibilidades de elaboração fraturada e figurada, como propôs Lasso em seu moteto, materializando as possibilidades de uso dos artifícios elocutivos e convenções dispositivas conforme os usos autorizados da linguagem musical.

Considerando que a função do exemplo no texto de Burmeister seja a ilustração dos preceitos formulados e que, enquanto ilustração, esses exemplos evidenciam as formas concretas dos ornamentos em sua aplicação no repertório corrente, colocando-as diante dos olhos dos leitores do tratado, os exemplos atestam a veracidade do uso, sua atualidade pela relação ao repertório vigente e da moda, e a aparência de verdade descrita como efeito. Além disso, o exemplo eleva a obra escolhida para essa função à condição de modelo, de referência e, seu compositor, à condição de autoridade, ou seja, qualifica-o como aquele que baliza as possibilidades de produção autorizadas, definindo os costumes e as formas de uso comum da linguagem. 
Lasso, embora católico e atuante em igrejas e cortes católicas ao longo de toda sua vida (HAAR, 2001, s. p.), foi referenciado por Burmeister como modelo para a formação de músicos luteranos. A recepção de Lasso pelos luteranos vem acompanhada da alteração de sentido do repertório desse compositor, da adaptação do sentido católico para o protestante, uma vez que a música religiosa cumpriria função ritualística e os ritos, sua função e contexto é que determinariam esse sentido.

A adoção de referências católicas para a música protestante evidencia o valor relativo das técnicas de produção, conforme concepção aristotélica, e o valor absoluto das técnicas de interpretação. A técnica, enquanto modo de operação, não é nem católica e nem protestante, mas é, antes de tudo, musical. A interpretação da coisa produzida, por outro lado, é condicionada por seu contexto de recepção e pelo horizonte de sentido daqueles que a apreciam. Nesse último caso, influenciam as questões dogmático-religiosas, políticas, educacionais e culturais. Dessa forma, podemos dizer que não exista propriamente um modo protestante de produzir música, pelo menos na época de Burmeister e antes dele, mas há uma forma protestante de interpretá-la. A valorização da interpretação alinha-se ao valor da palavra no exercício religioso luterano, balizado pelo princípio da sola scriptura, e à necessidade de acesso a ela, em suas diversas formas autorizadas de elaboração, como caminho de salvação.

Considerando o espaço que the é dedicado no tratado Musica Poetica, certamente Lasso foi reconhecido como aquele bom timoneiro que, pelo exemplo de suas obras, deve ter guiado as penas de muitos compositores. Mas, retomando Burmeister, como a natureza e o exemplo não bastavam para a boa formação na arte da música, os preceitos que o músico alemão formulou guiariam, em terra firme, como um farol, as ideias que definiriam o caminho que o barco iria tomar. A nós, músicos e pesquisadores do século XXI, seguindo esses preceitos e exemplos, cabe hoje retomar esses caminhos no mar de obras que nos foi legado, revivendo trajetórias, 
A função da análise na Musica Poetica de J. Burmeister

Cassiano de Almeida Barros

iluminando artifícios e trazendo, para o presente, o presente que a experiência do cantar, tocar e ouvir nos dá.

\section{Referências}

ARISTÓTELES. Poética. São Paulo: Editora 34, 2017. 232p.

BARTEL, Dietrich. Musica Poetica - musical-rhetorical figures in German Baroque Music. Lincoln and London: University of Nebraska Press, 1997. 471p.

BENT, Ian; POPLE, Anthony. Analysis. In: Grove Music Online. Oxford: Oxford University Press, 2001. Disponível em: https://doi.org/10.1093/ gmo/9781561592630.article.41862. Acesso em: 28 abr. 2020.

BOURDIEU, Pierre. As regras da arte: gênese e estrutura do campo literário. São Paulo: Companhia das Letras, 1996.

BURMEISTER, Joachim. Musical Poetics. New Haven \& London. Yale University Press, 1993.

DUNSBY, Jonathan; WHITTALL, Arnold. Análise musical na teoria e na prática. Curitiba: Ed. UFPR, 2011. 211p.

HAAR, James. Lassus [Orlando di Lasso], Orlande [Roland] de. In: Grove Music Online. Oxford: Oxford University Press, 2001. Disponível em: https://doi.org/10.1093/gmo/9781561592630.article.6002278212. Acesso em: 02 maio 2020.

HANSEN, João Adolfo. Aula Magna. Rio de Janeiro: Zazie Edições, 2019. $35 \mathrm{p}$.

LASSO, Orlando di. In me transierunt. Partitura. Transcrição da primeira edição, de 1562. Editada por Pothárn Imre, 2001. Disponível em: http://www2.cpdl.org/wiki/index.php/In_me_transierunt_irae_tuae_ (Orlando_di_Lasso). Acesso em: 15 jan. 2020.

LUTERO, Martim. Da autoridade secular. São Leopoldo/RS: Sinodal, 2017. 86p. 
A função da análise na Musica Poetica de J. Burmeister

Cassiano de Almeida Barros

PALISCA, Claude. V. Studies in the history of Italian music and music theory. Oxford: Clarendon Press, 2001. 522p.

RUHNKE, Martin. Joachim Burmeister: ein Beitrag zur Musiklehre um 1600. Kassel: Bärenreiter, 1955. $181 p$.

SANTOS, Cristiele; BARROS, Cassiano. A percepção musical e a apreciação musical: uma revisão de conceitos. In: Jornada de Estudos em Educação Musical, 6., 2016, São Carlos. Anais.... São Carlos: UFSCar, 2016. p. 305-313.

SKINNER, Quentin. The foundation of modern political thought volume II: the age of reformation. Cambridge: Cambridge University Press, 2004.

\title{
Financiamento
}

\author{
PNPD/Capes
}

\section{Publisher}

Universidade Federal de Goiás. Escola de Música e Artes Cênicas. Programa de Pós-graduação em Música. Publicação no Portal de Periódicos UFG.

As ideias expressadas neste artigo são de responsabilidade de seus autores, não representando, necessariamente, a opinião dos editores ou da universidade. 